of Psychiatry, Maudsley Hospital, to provide labora. tories in which integrated research by the Depart. ments of Neuro-endocrinology and Neuropathology may be carried out; up to $£ 36,500$ to the Department of Anatomy, University of Birmingham, to extend the research laboratories and animal accommodation ; up to $£ 25,000$ to the Department of Zoology, University of Edinburgh, to provide additional research accommodation; $\$ 50,000$ to the University of Western Australia to endow a Wellcome Research Department of Pharmacology ; up to $£ 17,000$ to the Institute of Medical Research, North Shore Hospital of Sydney, Australia, to build and equip laboratories for experimental medicine and surgery. In addition, three electron microscopes are being purchased at a cost of approximately $\mathfrak{£ 3 4 , 0 0 0}$ for indefinite loan to the following institutions: the Biophysics Research Unit of the Medical Research Council, King's College, London (Prof. J. T. Randall); Sir William Dunn School of Pathology, University of Oxford (Sir Howard Florey); London School of Hygiene and Tropical Medicine.

\section{Australian Society of Plant Physiology}

AT the University of Adelaide on August 19, plant physiologists from all the States of Australia attended a meeting convened by Dr. R. N. Robertson, head of the Plant Physiology Unit of the Commonwealth Scientific and Industrial Research Organization in Sydney, to consider the formation of an Australian Society of Plant Physiologists. The sixty scientists present decided unanimously to constitute such a society, with the aim of advancing the science of plant physiology. A constitution was adopted requiring the newly formed society to hold at least one annual meeting which will include a session for the presentation of scientific papers. At the inaugural meeting the following officers were elected. President, Prof. J. G. Wood (Department of Botany, University of Adelaide), Secretary, Dr. L. H. May (Waite Agricultural Research Institute, Adelaide), Treasurer, Dr. L. G. Paleg (Waite Agricultural Research Institute, Adelaide), Committee Members, Dr. N. P. Kefford (A.C.T.), Mr. L. A. Thomas (Queensland), Dr. J. F. Turner (New South Wales), Dr. P. Brownell (South Australia), Dr. D. M. Paton (Tasmania), Dr. D. J. Carr (Victoria), Prof. B. J. Grieve (Western Australia).

Some scientific papers were also presented at the inaugural meeting, and these indicated the wide range of interests of Australian physiologists. Nitrogen metabolism and the mechanism of ion uptake by plant cells, which have long been under study in Adelaide and Sydney respectively, were discussed in the light of recent work. Growth regulators formed the basis of several papers, ranging from synthesis in a symbiotic association, effects in photoperiodic and vernalization responses, to their effects in root contraction. Translocation, plant cell structure, sodium nutrition and the dynamies of growth in seedlings were among other topics presented. Abstracts of all the papers will be published in the Australian Journal of Science. At the next meeting, to be held in Canberra, it is planned to include agronomic and horticultural topics of interest to plant physiologists.

\section{Forests Products Research Laboratory}

THE Council for Scientific and Industrial Research has set up the following Steering Committee to look after the research programme of the Forest Products
Research Laboratory, in place of the Forest Products Research Board : Dr. B. K. Blount, deputy secretary of the Department of Scientific and Industrial Research (chairman); H. Douglass, a member of the Research Council and general secretary of the Iron and Steel Trades Confederation; L. J. Cardew Wood, managing director of Bell's Asbestos and Engineering, Ltd., and director of Bell's Asbestos and Engineering (Holdings), Ltd. ; the director of the Forest Products Research Laboratory (Dr. F. Y. Henderson); H. Wooldridge, head of the Stations Division, Department of Scientific and Industrial Research. Its terms of reference are : (1) to be responsible to the Research Council for the selection of projects and for the allocation of effort to them, within the financial resources allocated to the Laboratory and such other limits as may from time to time be imposed by the Council ; (2) to report annually to Council, submitting a research programme for the following vear. The Committee, which will be a full committee of the Research Council, is empowered to set up specialist sub-committees to provide technical advice on particular fields of work and especially on research in the field of pulping.

\section{Future of Timber Research in the United Kingdom}

Following recent announcements of its policy on forest products research, the Council for Scientific and Industrial Research recommends that the ultimate objective should be to concentrate all timber research at Princes Risborough, the site of the present Forest Products Research Laboratory. This would avoid the danger of overlap and unnecessary expense that might arise if separate laboratories were developed in different localities to serve the sectional interests of the timber trade and would ensure that the most effective use is made of the qualified staff and material resources available in the various organizations concerned with timber research. Discussions are being held with the Timber Development Association and the Forestry Commission to determine the type of organization which would most effectively co-ordinate the research requirements of their interests. As an initial step to the achievement of this objective, the Department of Scientific and Industrial Research is discussing with the Timber Development Association the possibility that part of the Princes Risborough site might be made available to the Research and Development Committee of the Association for immediate development, without prejudice to work at present in hand at its existing laboratories. Discussions will shortly be held with other trade organizations interested in timber research.

\section{Royal Observatory, Cape of Good Hope}

IN his report for 1957 H.M. Astronomer at the Cape of Good Hope records continued progress in many branches of astronomy (pp. 9. Cape of Good Hope: The Observatory, 1958). On the administrative side the increase in the number of visiting astronomers from outside South Africa and the growing co-operation between the Cape and Radcliffe Observatories are both valuable developments. The routine work of the Cape Observatory is undoubtedly the most important, and in some fields it is the only work of its kind being done in the southern hemisphere. The meridian circle programme of observations of about seven thousand stars is approaching completion, and a new working list of faint stars for use as standards in photographic plate 